\title{
The Plea of State of Necessity: A palatable normative framework for extraterritorial self-defense against Non- State Actors ${ }^{(*)(*)}$
}

\author{
El Alegato de Estado de Necesidad: Un marco jurídico digerible para la \\ legítima defensa extraterritorial contra Actores No Estatales
}

\author{
Moisés Montiel Mogollón ${ }^{* * *}$ \\ Universidad Iberoamericana (Ciudad de México, México)
}

\begin{abstract}
The UN Charter law governing self-defense is inadequate to address emerging modalities of armed violence caused by non-State actors located in the territory of non-consenting third States. This paper offers an alternative grounded in the state of necessity as a circumstance excluding wrongfulness as per the law of State responsibility. The contention is that in integrating the rationale behind necessity as an excuse for non-performance of obligations and the conditions and processes under article 51 of the UN Charter, the law allows for an exercise of extraterritorial self-defense against non-State actors which safeguards the territorial State's sovereignty and the need for a legal alternative of defense for the defending State without toeing the line of aggression.
\end{abstract}

Keywords: Self-Defense - Non-state Actors - State responsibility - State of Necessity - United Nations Security Council

Resumen: El régimen de la Carta de la ONU que tutela la legítima defensa es inadecuado para lidiar con las modalidades emergentes de violencia armada causada por actores no estatales situados en el territorio de un tercer Estado que no consiente a intervención. Este artículo ofrece una alternativa basada en el estado de necesidad como excluyente de la ilicitud de acuerdo con el régimen de la Responsabilidad Internacional del Estado. La proposición es que, al integrar el razonamiento que soporta a la necesidad como excusa para el incumplimiento de obligaciones y las condiciones y procesos existentes en el marco del artículo 51 de la Carta de la ONU, el derecho internacional permite el ejercicio de legítima defensa extraterritorial contra actores no estatales que salvaguarda la soberanía del Estado territorial y la necesidad de una alternativa legal de defensa para el Estado atacado sin cruzar la línea de la agresión.

Palabras clave: Legítima Defensa - Actores no Estatales - Responsabilidad Internacional del Estado - Estado de Necesidad - Consejo de Seguridad de las Naciones Unidas

(*) Editorial Team note: This article was received on September 2, 2021 and its publication was approved on November $28,2021$.

${ }^{* *}$ The author wishes to thank Santiago Vargas Niño and Alonso Gurmendi for their invaluable input in putting this piece together in record time, and also Ana Sofia Vargas for assisting in the research and, in general, for her unlimited patience. Views and mistakes are the author's own.

$\left.{ }^{(* *}\right) \quad$ LL.B. (Universidad Central de Venezuela), LL.M. (Fletcher School of Law and Diplomacy, Tufts University). Adjunct Professor of Treaty Law (Universidad Iberoamericana, Mexico) and Law of Armed Conflict (Universidad Panamericana, Mexico). Managing Partner at Lotus Soluciones Legales (Mexico City, Mexico). ORCID: https://orcid.org/0000-0002-9042-4098. Email address: mmontiel@up.edu. $\mathrm{mx}$. 


\section{Introduction}

To the best of current knowledge (Haque, 2021) (Modirzadeh, 2021) there is no normative enshrinement of the right selfdefense against non-State actors operating from the territory of a third-State without the need for consent of the territorial State (Paddeu, 2020) ${ }^{(1)}$ that is generally accepted or free from contestation. As last February's Security Council Arria-formula meeting ${ }^{(2)}$ made evident, the articulations of normativity are not enough in number or magnitude to show a customary extension of the right enshrined in article 51 of the UN Charter (Montiel, 2021), and State practice is far from general or consistent. The general position of States on this contention was aptly identified by prof. Modirzadeh as one of silence (Modirzadeh, 2021). The result of this is that the Charter law governing self-defense must be held to operate only among States for the time being.

Seeing as the joint reading of articles 2(4) and 51 of the UN Charter counterintuitively restrict self-defense to inter-State exchanges, and despite some ambiguous language by the UNSC on the issue ${ }^{(3)}$ (Ziccardi, 2007), the fact of the matter is that self-defense against non-State actors in the territory of third-State runs counter to the prohibition on the use of force and is outside of the personal scope of application of article 51. However, if the law governing the use of force fates States with suffering attacks under these circumstances with their hands tied, then, binding as it may be, it becomes a hindrance in the performance of duties owed to citizens and an enabler of irregular threats which empties the text and spirit of the UN Charter and the core principles of modern international law.

Such a position would also be inconsistent with the expansive caveat included in article 4 of A/RES/3314 (XXIX), which could be reasonably interpreted to include -to borrow the language from A/RES/2625 (XXV) as the definition of aggression does- the inaction or toleration of irregular forces, armed bands, or mercenaries meaning to violate the territorial integrity of a third State. Also, the latter document upholds the duty of a State to refrain "from acquiescing in organized activities within its territory directed towards the commission of such [acts of civil strife or terrorist acts in another State], when the acts referred to in the present paragraph involve a threat or use of force" (UN, 1975). It is worth noting that the Annex to resolution A/RES/2625 (XXV) seems to be one of the likeliest candidates to be considered jus cogens and thus occupies a place of honor as far as norms go, as evidenced by the Fourth Report of the International Law Commission on Peremptory Norms of General International Law (ius cogens) on 2019 (International Law Commission, 2019), and, in any event, it is an indisputable expression of cornerstone principles of international law.

From the above observed, the onus seems to be on the territorial State to prevent and deter the attack by non-State Actors (NSAs going forward) upon the threatened State. This much can be easily inferred. However, this paper is not concerned with the duty of the territorial State to avoid irregular armed bands from inflicting damage on the territorial integrity or the political independence of third States. It attempts to deal with the question of resources available to the third State in question -the recipient of the attack- when the attack by NSAs is imminent or actual and the territorial State fails to carry out its duties to prevent the attack. Surely, the answer cannot be, as pointed above, that the would-be victim is powerless to preempt, halt, or repel the attack. But, then again, such an action appears to be at odds with article 51 , which normatively excludes instances of self-defense against actors other than States.

What if the answer to this conundrum is not to be found on article 51 of the Constitution of the UN, but rather on a simultaneously older and newer regime?

This piece posits that the breach of obligations owed to the territorial integrity and sovereignty of the territorial State where non-State armed groups can be justified if the criteria of the state of necessity under the regime of State responsibility is met. While some authors opine that the regime of State responsibility is incompatible with the activity

(1) Notwithstanding some attempts framed as customary law, such as those of the Caroline and Gorostiza Standards, which will be discussed infra, especially in their allegedly normative dimension.

(2) Defined by the UN Secretariat as "very informal, confidential gatherings which enable Security Council members to have a frank and private exchange of views, within a flexible procedural framework, with persons whom the inviting member or members of the Council (who also act as the facilitators or convenors) believe it would be beneficial to hear and/or to whom they may wish to convey a message. They provide interested Council members an opportunity to engage in a direct dialogue with high representatives of Governments and international organizations - often at the latter's request - as well as non-State parties, on matters with which they are concerned and which fall within the purview of responsibility of the Security Council" (UN, 2021, par. 2).

(3) See UNSC Resolutions S/RES/1373 (2001) of September 28th 2001 and S/RES/1368 (2001) in their preambulatory clauses. 
of the Security Council under the use of force regime, arguing that the declaration of unlawfulness of a conduct is materially different than the political assessment carried out by the Council (Tsagourias, 2011), there is no impediment for the UNSC to incorporate the examination of the operational requirements for the excuse of necessity into its discussions, a point which is discussed at large in this paper. This, in keeping with the logic of articles 24,39 , and 51 of the UNC, which recognize the organism's near-monopoly on peace and security issues and task it with receiving notifications of self-defense or any other situations concerning international peace and security, acting in accordance with its guarantor role. Additionally, the composition of the Council and its being bound by international law would allow incorporation of the requisites laid down by the ILC's 2001 Draft Articles on Responsibility of the State for Internationally Wrongful Acts (DARSIWA going forward) in assessing whether a state of necessity actually existed at the moment the counterattacks were carried out and if the breach is justified and thus not a violation of international peace and security (and therefore of international law).

In order to answer these questions, this paper is divided into three sections. The first one is concerned with analyzing the shortcomings of self-defense, as enshrined in the UN Charter, to address the question of how States should respond to attacks by NSAs on the territory of a third State that has not given its consent for intervention. In doing so, this section explores the limits of the inherence and non-constriction features of selfdefense as included in the Charter. It also reviews the existing debate on the customary law on self-defense and the doctrinal discussions concerning different standards that enable selfdefense against NSAs (with varying degrees of normativity) such as the unwilling/unable doctrine and the Caroline and Gorostiza incidents (and their ensuing doctrines), which have contributed to shape the customary understanding of the law of self-defense against NSAs.

The second section seeks to shed light on the institution of the state of necessity and the current state of the art concerning the doctrine to test its viability to exclude responsibility for instances of self-defense against NSAs. To that end, it dissects the conditions for the operation of the excuse as they have been codified by the International Law Commission in 2001 and its reception in international law. This part takes special note of the relevant dicta of the International Court of Justice which have substantially shaped the modern understanding of the exception of state of necessity with a view to provide insights into the correct interpretation of the requisites of essential nature of the interest at stake, gravity, and imminence of the threat that would then justify the breach and preclude wrongfulness. This with a view to posit the compatibility of the doctrinal and jurisprudential operation of said requisites with the conditions of proportionality and necessity that flow from article 51 of the UN Charter (Kretzmer, 2013).
The third section comprises the pièce de resistance of this work. It explores how should the claim of state of necessity operate (with due regard to the previously laid conditions) in lieu of the claim of inter-State self-defense at the UNSC, without discarding the same requirements of proportionality and necessity. It also analyzes the issues of the authority of the Council to entertain such a claim, based on its primary responsibility for the maintenance of international peace and security and its ability to declare any given occurrence as a threat to international peace and security and consequently act on it.

The presumptive conclusion of this piece is favorably oriented towards the legality (and convenience) of enabling the plea of necessity before the UNSC as a factor excluding wrongfulness when actions preliminarily constituting a breach of article 2(4) must be taken in order to halt, repel, or maybe even preempt an armed attack carried out by a NSA from the territory of a third State, provided that such a State is not allowing said actions but refuses to permit the attacked State to intervene, which leaves the originally attacked State short of legal options to defend its own territorial integrity and political independence.

The intention behind this proposition is to provide a normative framework, compatible with the law as it currently exists, that can move the discussion away from contentious and discretional standards with no normative traction, such as the 'unwilling and unable' doctrine, and to provide a modicum of certainty for the international community as to when exceptions to territorial integrity can be tolerated. In repurposing the UNSC by way of extension of its material capability to analyze instances of self-defense against NSAs in the territory of a third non-consenting State, the analysis and qualification of any given instance of use of force becomes simultaneously subject to legal and political scrutiny and may be held accountable if it exceeds the limits. At the same time, it constitutes an honest attempt to curtail seemingly unfettered conduct by States when conducting military operations in the territory of others.

As a forethought, last year, a much admired countrywoman took the law of 
State responsibility out for a stroll in order to determine whether consent was "a defense or part of the definition of the prohibition of force" (Paddeu, 2020), even if the key point of that piece is only tangent to the discussion proposed here, her conclusion serves as the perfect starting point of this paper: any use of force which is inconsistent with the UN Charter system is illegal and consent (or necessity in this case) is a defense -or a justification- to exclude responsibility for the breach. Therefore, and in the interest of safeguarding the territorial integrity and political independence of the defending State, recourse must be had to already existing valid law if self-defense is to be claimed against NSAs in the territory of a third State without its consent, and the UN Charter and international law are to be upheld at all.

Additionally, this paper builds substantially on Terry Gill and Kinga Tibori-Szabó's paper of 2019, which outlined in exquisite detail the operation of necessity in the context of the customary law governing self-defense against NSAs in the territory of a third non-consenting State. In it, they claimed that "necessity (...) serve[s] as both the driver and the limiting function of the exercise of self-defense" (Gill \& Tibori-Szabó, 2019). This paper aims to take up the call made by the authors to provide a normative framework susceptible of providing "some adjustments" to our current thinking about necessity in order to make it actionable in the existing Charter system governing the use of force and self-defense.

\section{The inadequacy of Charter law governing the use of force to encompass self-defense against NSAs in the territory of a third State without its consent}

When thinking about the law governing the use of force in international law, the rules appear to be self-evident. Outside of UN Security Council (UNSC or the Council going forward) authorization under a Chapter VII resolution or individual and collective self-defense, the use of force against the territorial integrity or political independence of another State, or in any manner inconsistent with the purposes of the UN is prohibited (4) (United Nations, 1945) and thus considered an internationally wrongful act under the label of aggression, pursuant to articles 2(4) of the UN Charter (UNC going forward), and article 5(2) of
General Assembly resolution 3314 (XXIX) of 1974 (United Nations, 1974) which is largely held to be reflective of customary norms (Drnas de Clément, 2002) and even of jus cogens rules (Torp Helmersen, 2014), which has recently been welcomed into the fold of international crimes under the competence of the International Criminal Court.

In fact, article 3 of A/RES/3314 (XXIX) singles out several actions which fall under the category of aggression. For example: invasion or attack of the territory of another State, bombardment or use of any weapons against the territory of another State, use of force exceeding the limits of authorization of the territorial State when it has consented to military presence of the attacking State's forces, or allowing a State's territory to be used by a different State for attacking a third State, just to name a few (United Nations, 1974). Upon revision a constant becomes manifest: these banned uses of force are all conceived as necessarily and exclusively between States.

The system, dating back to the San Francisco conference in 1945, was built by and for States. It has a clear state-centric dynamic embedded in it (Kotlik, 2017), reflective of the paradigm that governed international law at the time (Gill \& Tibori-Szabó, 2019); the main (and almost sole) subjects of it were States. Individuals or private groups were held to have little or no agency in the legallyrelevant exchanges governed by this branch of the law ${ }^{(5)}$. As a result, the UN Charter (UNC henceforth) system governing force does not take into account the organized used of armed violence carried out by or against non-State entities when it is not tolerated or allowed by the territorial State, which would then necessarily fall under the 'domestic matters of the territorial State' label to the chagrin of the threatened or attacked State.

(4) Without prejudice to exceptions created by regional agreements like NATO, or the OAS which largely follow the same logic with minor deviations. In the case of the Inter-American Treaty of Reciprocal Assistance and its potential application to situations other than inter-State use of force. See Franck, T. (1970) "Who Killed Article 2(4)? Or: Changing Norms Governing the Use of Force by States". American Journal of International Law, 64(5), 809-837, however this point will be revisited later on in this paper.

(5) Except maybe in the realms of international criminal law, international humanitarian law and international human rights law, all of which were prominent features of the mid-20th century's legal landscape with the Nuremberg and Tokyo war crimes tribunals and their ensuing developments. 
Since its inception, the UN's use of force system was conceived as a mechanism to sort out disputes between States that decided to renounce war as means of dispute settlement. Picking up where the Kellogg-Briand Pact left off, the San Francisco Conference of 1945 was inaugurated by President Truman to the following tune:

(...) The essence of our problem here is to provide sensible machinery for the settlement of disputes among nations, Without this, peace cannot exist. We can no longer permit any nation or group of nations to attempt to settle their arguments with bombs and bayonets (Truman, 1945, par. 35).

This same spirit, which evidently guided the endeavors of the San Francisco Conference, is the reflection of the commitments made at Yalta and Dumbarton Oaks (Britannica, 2021). Notice, in the latter, articles 3 and 4 of Chapter VIII, section A, about pacific settlement of disputes among States. The intent to regulate was clear: uses of force between States should be banned by the future organization to replace the League of Nations. These commitments were the forebears of the current UNC use of force system. However, and after more than seven decades, the dynamics of the international arena have outgrown the material scope of application of the Charter's use of force system by and large.

Interstate armed conflict, whether aggressive or not, within the meaning of common article 2 of the 1949 Geneva Conventions, have increasingly become an exceptional situation. Much in the same way as isolated uses of force between States falling short of that threshold. This could be celebrated, partly, as a success of the UN system (if one feels obsequious) or as a consequence of a myriad other factors having to do with complex interdependence (Keohane \& Nye, 2000). However, conflict remains a constant, even if it changes in formand parties. This observation highlights the apparent mismatch between Charter law governing the use of force and current reality, which now encompasses actors other than States.

Arguably, the reference in article 51 to the non-constriction of the inherent right of self-defense of States was designed to respect dimensions of operation outside of the scope of application of the article itself (Bethlehem, 2021). This would mean that the scope of customary self-defense at the time of the drafting of the Charter may have indeed exceeded that of only interstate uses of force ${ }^{(6)}$. However, as observed by Gill and Tibori-Szabó (2019), several authors argue that the limitation implied by the wording of article 51 UNC was deliberately intended to reduce the scope of action of self-defense even beyond the Charter(Tladi, 2013). As pointed out: "[o]ne of the controversies regarding the effect of the Charter on the pre-1945 right of self-defense concerns NSAGs and whether these groups can qualify as authors of an armed attack" (Gill \& Tibori-Szabó, 2019, p. 475).

The question raised by the authors follows the logic of broadening the material and personal scope of application of article 51 to see whether the right of self-defense can encompass armed attacks by NSAs. Even with the diverging opinions of scholarly commentators on the matter, the application of interpretation methods enshrined in the Vienna Convention on the Law of Treaties of 1969 (VCLT) on articles 31-33 would seem to foreclose such attempt. The Charter is an international treaty signed by States and incapable of producing obligations outside of that personal scope. More to the point, the travaux préparatoires of the UNC are clear evidence that:

[T] he drafter's primary objective was to regulate State behavior rather than address the dangers posed by NSAGs. Accordingly, during the drafting process, the principal discussions regarding article 51 centered on the concerns of Latin American States that the Charter and the powers of the Security Council did not supersede their regional arrangements for collective self-defense (Tibori-Szabó, 2011, p. 474).

Similarly, the personal scope of applicability of article 51 was not discussed during the San Francisco Conference. As Gills and Tibori-Szabó report, an earlier draft of the article included the precision that it referred to attacks by a State against any other member State, but it was later dropped without a reason on the record for it (2019). This silence, while in and of itself not terribly indicative of anything, allows for context to be brought to bear on account of the lack of literal or textual interpretations to be had. Thus, systematic interpretation forces the reader to address article 51 in the context of article 2(4) of the same document. In the latter, the use of force is prohibited among States, and it would stand to reason that, being the exception to article

(6) This idea certainly finds support in pre-existing doctrines and standards concerning uses of force against non-State actors in the territory of third States such as those laid out in the Rainbow Warrior case, or the Caroline and Gorostiza Incidents. The ensuing standards will be explored in more depth later on the piece. 
2(4), article 51 would inexplicably have a wider ratio personae spectrum, this same reasoning is exhibited by authors such as Mary Ellen O'Conell (2013), and Rona \& Walla (2013).

A State-centric reading of the result of the joint reading of articles 2(4) and 51 of the UNC, in line with the freedom principle enshrined in the PCIJ's Lotus Case (1927), would thus mean that if not explicitly prohibited, then the resort to self-defense against NSAs in the territory of a third non-consenting State would be lawful (Gill \& Tibori-Szabó, 2019). However, upon close examination, this view doesn't hold. This is because any use of force conducted against a NSA will necessarily occur on the territory of a third State ${ }^{(7)}$ and will then amount to a violation of article 2(4) UNC in prejudice of the territorial State unless an exception or justification can be proven.

This latter point also fits within a teleological reading of the UNC. The object and purpose of article 51 in the larger context of the UNC is evident from article 2 of the Charter, which lays out the principles of the Organization. The very object of the treaty is to preempt uses of force against the territorial integrity and political independence of member States. The discrepancy between the target of the attack (the NSA and not the State) and the effects, forcibly suffered by the territorial State, don't appear to be distinguishable, even if the case has been made by authors such as Trapp (Trapp, 2015)(8). The problem with using intentionality of targeting as a rationale for toleration is that it results impossible to ascertain from an objective model of responsibility, such as the one prevalent in international law.

One further avenue to analyze whether the use of force system of the UNC can cater to the situation under study is that of subsequent practice (under the VCLT as complementary and subsidiary method of interpretation) relative to UN Charter law (Gill \& Tibori-Szabó, 2019). As is usual in these instance, scholarly commentary covers both positions. In the affirmative, authors such as Murphy (2002) and Antonopoulos (2008) posit that the pre-Charter customary admissibility of self-defense against NSAs in the territory of a third non-consenting State remains untouched and therefore, while separate from the UN's use of force system, the exercise of self-defense is legal. This is unconvincing insofar as it adds nothing to consider in the evolution of practice surrounding the UN Charter but rather just offers the existence of a parallel and unconstrained customary regime. Another shortcoming of this position is that it does not take into account the location of the NSA and covers only those attacks occurring in the territorial jurisdiction of the attacked State.

Another point to consider by those defending a parallel customary regime allowing for the claim of self-defense tantamount to that of article 51 UNC is the Charter's nonsupersession clause located in article 103. In principle, this rule would preclude the possibility of change in the terms laid out in the Charter by any other international agreement which would then negate the legality of the so-called parallel customary regime if it runs counter to the exclusively inter-State domain of article 51. However, there is contention on whether article 103 UNC is applicable to customary law or whether it only applies to international agreements understood as treaties (Glennon, 2001) which would render this particular argument inconclusive, but still worth considering.

Regardless of the conclusion on the interpretive discrepancy of article 103 UNC, another line of defense that would go against the possibility of both the enlargement of article 51 UNC by way of practice and against the existence of a stand-alone customary permission. This would be the purported jus cogens nature of the prohibition of the use of force (Torp Helmersen, 2014). While the determination and effects of jus cogens rules are still hotly contested (ILC, 2016), one thing is clear: no norm of jus cogens character may be derogated from unless such modification comes from a subsequent peremptory rule. Naturally, this would apply squarely should the contending norm be found in a treaty (as per article 53 VCLT), which is notably not the case here, nevertheless it is still noteworthy that there is resistance by the normative establishment to accept changes to rules endowed with such superior character ${ }^{(9)}$.

Building on this, the last few years have witnessed the resurgence of the so-called

(7) With the potential exception of uses of force carried out in res communis places such as the High Seas or Outer Space, which -on account of lack of regulation in one case, and lack of potentiality, in the other- are excluded from the analysis of this piece.

(8) The main point of this proposition is that self-defense against NSAs may be permissible to the extent that the territorial State itself is not targeted.

(9) In its 2019 report on peremptory rules of general international law of the ILC, the Special Rapporteur, Mr. Dire Tladi, has put forth the notion that jus cogens rules may not be derogated by contravening custom or desuetude. While the author remains unconvinced with the identification and operation of this special category of norms, it is noteworthy that institutions which do support it are convinced that these norms may not be derogated from under any circumstances. 
'unwilling or unable' doctrine on the realm of jus ad bellum. While articulations along the same lines can be found as far back as 1970 by the Nixon administration in the US (Heller, 2019), 1976 by Israel on its Entebbe raid (O'Connell, 2019), or 1981, again by Israel, concerning its armed activities in Lebanon (Gill \& Tibori-Szabó, 2019), it has become prominent in the post $9 / 11$ world and especially in the context of the so-called 'War on Terror' that followed the invasion of Afghanistan. It also was (even if not mentioned out loud) the preponderant subject of the above mentioned Arria Formula meeting convened by Mexico on February 2021.

The 'unwilling and/or unable' proposition is built upon the premise that the territorial State has an active duty to prevent any damage caused to third States originating on its own territory, following on the ICJ's Corfu Channel Case (ICJ, 1949) recognition of the international obligation not to cause or allow harm to other States, which is also enshrined in A/RES/2625 (XXV) of 1970 as pointed out above. Thus, the doctrine posits that "a victim state has the right to engage in lawful extraterritorial self-defense when the host state is unwilling and/or unable to mitigate or suppress the threat posed by domestic NSAs" (Williams, 2013, p. 620).

The doctrine allegedly finds its pedigree as an update of the Caroline standard (DeLaurentis, 2021), although this genealogy is a bit doubtful (Heller, 2019). It originally posited that anticipatory self-defense against NSAs, in order to be lawful, should comprise "a necessity of self-defense, instant, overwhelming, leaving no choice of means, and no moment for deliberation" (Webster, 1837). Precisely because of the immediacy of the action required and its overwhelmingness and gravity. The doctrine was held to be a lawful exception to the then-not so absolute prohibition on the use of force and went on to constitute the foundation of the customary law of self-defense in the pre-Charter era.

However, in trying to expand the material reach of application of the Caroline test to justify the 'unwilling and/or unable' doctrine, even if taking into account other relevant incidents like the Gorostiza standard which notoriously centered the discussion around the need to prove necessity before allowing extra-territorial self-defense (Gurmendi, 2020), the test of time has been unfavorable towards the exception. The paucity of general practice seems to belie the notion that it has attained customary character (Chachko \& Deeks, 2016), much in the same way that the invocation of the exception has been all but consistent (Gill \& Tibori-Szabó, 2019). Additionally, it is riddled with ambiguities which threaten international peace and security in the absence of clear regulation. The appreciation put forth by Sharma and Agarwal hits the mark when they comment that the effet utile of the doctrine is to circumvent the need to obtain the host state's consent. This can naturally threaten the international order absent a strict regulation (Sharma \& Agarwal, 2020). The authors further posit that the doctrine -due to its inconsistent invocation and application- has failed to garner customary status (Sharma \& Agarwal, 2020).

The 'unwilling and/or unable' doctrine presents a perfect example of why trying to artificially expand the limits of article 51 UNC is incompatible with the legal regime laid out by the treaty itself. The arguments put forth by States, such as France, Denmark, Egypt, Lebanon, Colombia, Uganda, or India, doubting the legality of the doctrine is highly telling (Chachko \& Deeks, 2016) in that they situate Charter law as the starting point for any discussion on self-defense, which then complicates any attempt at enlarging the scope of application (personal and material) of article 51 UNC. These sentiments are echoed and expanded further by States such as Mexico (who convened the Arria Formula meeting), who have outright rejected the legality of the doctrine on the same basis (De la Fuente, 2021).

On the camp of those who argue against the legality of claiming self-defense in terms of article 51 UNC as a right to be exercised against NSAs located in the territory of a third non-consenting State, the arguments put forth by Kunz (1947), Stahn (2003), Kammerhofer (2007) and Orakhelashvili (2015) ring most persuasive. In sum, these authors support the conclusion that the use of force system built into the UN Charter was designed exclusively for inter-State exchanges of violence ${ }^{(10)}$ and thus negate the possibility of self-defense being a feasible or legal claim in the particular instance of scrutiny of this paper.

(10) With the notable inclusion of instances of armed attack carried out by non-State actors only if attribution or substantial involvement of a State can be proven. This scenario has been the subject of ample discussion and has been endorsed by the International Court of Justice in rulings like the Nicaragua case (Nicaragua v. USA) and the Armed Activities case (DR Congo v. Rwanda). In both instances, the Court has found that if there is a sufficient level of control or involvement of the State in the activities of the armed group then the actions may be attributable to the State for determination of international responsibility. 
In practice, the United Nations Security Council, tasked with qualifying the legality and correctness of instances of selfdefense under article $51 \mathrm{UNC}$, has been less than receptive to claims of self-defense against NSAs in the rare opportunities when it has said anything at all. Resolutions S/RES/273 of 1969, S/RES/294 of 1971 dealing with this exact claim being put forth by Portugal or resolutions S/RES/265 of $1969, \mathrm{~S} / \mathrm{RES} / 313$ of 1972 , or S/RES/467 of 1980 concerning the alleged exercise of extra-territorial self-defense by Israel bear witness to the little sympathy the Council holds for this position. However, as will be noted below, the agency of the Council as a law-determining body remains contested and the politics that are an integral part of its operation make it difficult to ascertain whether the rejections is founded on politics or on law.

On a similar note, and (mostly) unburdened by the cloud of politics, the ICJ has also observed that it does not look kindly to the claim of self-defense under article 51 UNC when used against non-State actors. In the Wall advisory opinion and the Armed Activities ruling, the ICJ displayed discomfort with applying the right of self-defense to non-State attacks lacking a clear connection to a State (Arimatsu \& Schmitt, 2021). This would confirm that, in the Court's opinion, the claim of selfdefense under article 51 of the UNC is restricted to inter-State exchanges of force ${ }^{(11)}$.

As shown above, and recognizing that the issue has warranted substantial discussion, it's safe to say that caution advises against the legality of claiming self-defense when the author of the attack is not a State. Much more so if the purported actions to repel, halt, or preempt the attack are to have effects or be carried out in the territory of a third State that has not consented to the action and regardless of whether the territorial State has complied with its duty to not tolerate or harbor NSAs hostile to the defending State.

That is, of course, a matter of law, which, as pointed out earlier, runs counter to logic and to the defending State's own right to the respect of its territorial integrity and political independence. As a matter of fact, the proposition that the defending State's hands are tied, and it is fated to suffer the attack out of respect for the territorial integrity of the territorial State is entirely antithetic to its legitimate expectations under article 2(4) UNC and also absurd.

The conclusion then, is that Charter law governing selfdefense is largely inapplicable to situations where the author of an attack is not a State, but the offense still originates within the territory of another State and must be dealt with in its territory. However, all is not lost. There is law outside of the UN Charter (and compatible with it) that may be used for this exact purpose, without prejudice to the system of use of force contained inthe treaty. Enter in the ILC's Draft Articles on Responsibility of the State for Internationally Wrongful Acts article 25: the plea of necessity.

\section{The state of necessity as a circumstance precluding wrongfulness under the law of State responsibility}

As a forethought to this section, it should be noted that in the case under analysis, there is no adequate or materially coincident regulation (conventional, customary, or otherwise) that caters to the specific situation of exercising any type of self-defense against NSAs located in the territory of a third State that refuses permission to deal with the threat. As shown above, Charter law and its customary equivalent governing the use of force do not provide sensible alternatives to this situation. In absence of any regulation in primary rules, the default option ${ }^{(12)}$ becomes the Draft Articles on the Responsibility of the State for Internationally Wrongful Acts (Crawford, 2019).

Furthermore, before addressing the proposition of the plea of necessity in the context of the DARSIWA as a more deft way to navigate instances of self-defense against NSAs in the territory of a third non-consenting State than conventional self-defense in the Charter context, it is useful to note (as detailed above) that diverse attempts have been made to provide frameworks to enable the practice. Most notable from the academic trenches is the discussion started by Daniel Bethlehem

(11) In the interest of precision, it must be annotated that the ICJ, in the Wall opinion and the Armed Activities Case, has only condemned instances of self-defense carried out against the State harboring the NSAs and not the NSAs themselves. However, this position could be held to reinforce the impossibility to separate the personal and territorial aspects of self-defense against NSAs in the territory of a third non-consenting State, as pointed out above. Additionally, the silence of the Court as to this specific situation (which it did not include as a lawful option) should be read in keeping with the integrity and superiority of the prohibition of the use of force in substantive terms.

(12) Especially since the articles restrict their applicability if the particular material regime contains any lex specialis dealing with declaration of responsibility. 
and hosted by the American Journal of International Law of the so-called 'Bethlehem Principles' (Bethlehem, 2012). Suffice it to say that the best argument against Bethlehem's proposition is that it has failed to generate cohesion among States who find themselves attempting to justify their attacks on the territory of third States (even if bits and pieces of the argument appear sparsely every now and then in different doctrinal enunciations). The most cogent expression of the inadequacies of that proposition is that:

[D]espite their constant invocation, the notions of necessity, imminence, and proportionality are fraught with conceptual ambiguity and are notoriously difficult to apply in practice. By relying heavily on necessity, imminence, and proportionality, Bethlehem imports these difficulties into his principles (Akande \& Liefländer, 2013, p. 569).

The criticisms to this proposition are not exclusive to Bethlehem's principles. As noted above, neither State practice, expert commentary, nor even jurisprudence have so far come up with a regime well-suited and properly tailored to cater to this very particular situation. That is, presumably, the reason why exercises like the Arria Formula meeting convened by Mexico in February 2021 are simultaneously so useful and so problematic. The lack of clarity and precision ailing the components of selfdefense, in the context of its invocation against NSAs, make it impractical and cumbersome and difficult to assess even after the fact.

This paper contends that self-defense (be it within the Charter context or without) is ill-suited to answer to the new realities affecting the current conventional and customary use of force dynamics. As observed earlier, this normative gap would force the conclusion that States are fated to suffer harm when the particular conditions studied here present themselves.

Within the very context of the ILC's Draft Articles, article 21 covers self-defense as a ground for exclusion of responsibility, but as it was mentioned before, that system is designed for inter-State instances of self-defense and therefore does not govern the specific case analyzed in this situation, this becomes evident in comment (5) of article 21 of the DARSIWA which claims that "(5) The essential effect of article 21 is to preclude the wrongfulness of conduct of a State acting in self-defense vis-àvis an attacking State. (...)" (ILC, 2001). This occurs because the rules concerning self-defense in the Articles essentially copy the Charter system of self-defense. In fact, the reference to article 51 UNC is explicitly built into article 21 of the DARSIWA, as is the subjection to the requisites of proportionality and necessity under the UN Charter law.

As a matter of legal logic, claiming self-defense when the author of the attack is not another State creates issues of contradiction with article 2(4) of the UN Charter. If one State's right of self-defense is exercised, then there is a necessary infringement upon the right of territorial integrity of the territorial State. Simply put a defending State cannot repel, halt, or counter an attack launched by an NSA on the territory of a third State without exercising force in the territory of that State and therefore breaching its territorial sovereignty. This because the UN Charter bars self-defense against actors other than States. This flies in the face of Aristotle's logical non-contradiction principle, where two opposing premises cannot be simultaneously and entirely true. This is precisely why self-defense is designed as an exception to the right of territorial integrity of the territorial State (when it is itself the attacker) which has opened up to the infringement by virtue of its own violation of the other State's right to territorial integrity or political independence. The resemblance to countermeasures is, evidently, uncanny. This is because it is the aggression of the attacking State that gives way to the right of self-defense of the defending State. That is, however, not the case when attacker is not a State. The ILC espouses a similar logic in its commentated version of the Draft Articles. It goes on to say:

(1) The existence of a general principle admitting self-defense as an exception to the prohibition against the use of force in international relations is undisputed. Article 51 of the Charter of the United Nations preserves a State's "inherent right" of self-defense in the face of an armed attack and forms part of the definition of the obligation to refrain from the threat or use of force laid down in Article 2, paragraph 4 . Thus, a State exercising its inherent right of self-defense as referred to in Article 51 of the Charter is not, even potentially, in breach of Article 2, paragraph 4 (ILC, 2001, p. 24).

Read in the context of article 21 as a whole (especially in its' $5^{\text {th }}$ and $6^{\text {th }}$ comments), this exclusion of breach can only operate when the hostile act occurs amongst States. Given that self-defense is an exception to the unlawfulness of the use of force, such an exception may not be expanded absent the clear intent to do so on the part of States. To date, this issue is hotly contested as shown above, and no clear articulations of opinio juris sufficient in number seem to exist, as the coverage of February's Arria Formula has conclusively shown. 
The inadequacies of self-defense under Charter law and its copycat in article 21 of the DARSIWA yield no useful answers to the question of self-defense against NSAs operating from the territory of a third non-consenting State. However, a sensible alternative may -as promised at the outset of this piece- be found in article 25 of the DARSIWA covering the plea of necessity. The article in question reads:

Article 25. Necessity

1. Necessity may not be invoked by a State as a ground for precluding the wrongfulness of an act not in conformity with an international obligation of that State unless the act:

(a) is the only way for the State to safeguard an essential interest against a grave and imminent peril; and

(b) does not seriously impair an essential interest of the State or States towards which the obligation exists, or of the international community as a whole.

2. In any case, necessity may not be invoked by a State as a ground for precluding wrongfulness if:

(a) the international obligation in question excludes the possibility of invoking necessity; or

(b) the State has contributed to the situation of necessity (ILC, 2001, p. 80).

As observed by Arimatsu and Schmitt, "[n]ecessity is a core principle of international law that operates in diverse ways within different legal regimes. For example, it is a condition (the law governing the use of force), a foundational principle (international humanitarian law), a limitation (international human right law), and a legal defense (international criminal law)" (Arimatsu \& Schmitt, 2021, p. 1182). Being a core principle of the normative system, its existence prior to its inclusion in the 2001 DARSIWA is pretty much uncontested by both the International Court of Justice and the ILC (Arimatsu \& Schmitt, 2021) and by scholarly commentary at large. Evidence of its role in international law can be found as far back as Grotius, who wrote of its operation in the context of jus in bello (Boed, 2000), or -in the context of self-defense- in instances like the Caroline incident or the Gorostiza Pamphlet (Gurmendi, 2020).

In its modern sense, the ILC offers a definition of necessity in the context of justifications in the following way:

(1) The term "necessity" (état de nécessite) is used to denote those exceptional cases where the only way a State can safeguard an essential interest threatened by a grave and imminent peril is, for the time being, not to perform some other international obligation of lesser weight or urgency. Under conditions narrowly defined in article 25 , such a plea is recognized as a circumstance precluding wrongfulness (ILC, 2001, p. 24).
Note how, from the outset, necessity is presented by the DARSIWA as a negative formulation. This gives credit to its extremely exceptional nature (Paliouras, 2016) which has also been noted by the World Court on its Gabcikovo-Nagymaros Project case when it highlighted its very exceptional character (1997). The wording utilized by the Commission certainly confirms its last resort nature, not unlike the one that would be made under circumstances so grave that left no moment for deliberation and no choice of means. This exceptional nature is compatible with the pacta sunt servanda owed to third States and is precisely why it makes for a palatable way to navigate the situation presented in this paper.

From its debut in classical law systems and to this day, the state of necessity is indicative of the general unlawfulness of the action taken in the specific context in a logic akin to that of justifications or excuses (Paddeu, 2020). However, recourse to it is justified insofar as it seeks to protect a more valuable interest than the one being harmed. Boed writes in this context that:

[W]hen a threat to self-preservation arose, it was considered justified to take any steps necessary to preserve one's existence, even if such steps would have been unlawful had they been taken in the absence of a threat to self-preservation (Boed, 2000, p. 4).

As observed by the same author, "the balancing test in the provisionally adopted text of article 33 of the ILC's Draft Articles on State Responsibility is designed to weigh inconsistent interests of two States (...)"(13) (Boed, 2000, p. 3), from there it follows, that the drafters of the articles identified the norms of State responsibility as flexible in deference to essential interests of States without necessarily making them trump cards that would void of content and binding character the obligations of the State vis a vis each other.

(13) See also Report of the International Law Commission on the Work of its Twenty-Seventh Session, U.N. Doc. A/10010/Rev.1 (1975), 51-59, U.N. Doc. AICN.4/SER.Al1975/Add.1; Report of the International Law Commission on the Work of its Thirty-Second Session, U.N. Doc. A/35/10 (1980), 26- 34, U.N. Doc.AICN.4/SER.A/1980/Add.1. 
Its outstanding character has to do with its linkage, in classical times, to the innate right of self-preservation which is natural to every State. In fact, Boed (2000), goes on to note that Hugo Grotius himself accounts for the recognition of the right to selfpreservation as far back as roman law, and that it was later picked up by the social contract writers such as Locke, Hobbes, and Rousseau. Thus, the historical logic behind the state of necessity is not to remove the unlawfulness of the action taken, but rather to shift the discussion towards the necessity that justifies the illegality in a particular factual context. As a consequence of this shift in the terms, responsibility for the trespass cannot be exacted by the aggravated party because of the extraordinary nature of the threat or harm caused to the State claiming the operation of necessity. This is consistent with the nature of international law as a system of voluntary self-limitation (Jellinek, 1880) enshrined in the Lotus Principle (PCIJ, 1927).

However, not every whim of the State can fall under this normative exception and the reach of necessity has been narrowly defined ever since its Grotian inclusion. Rodick identifies six conditions in the writings of the seminal scholar for the exception of necessity in the context of inter-State warfare: (1) absence of criminal intent, (2) existence of real danger to vital interests, (3) temporal imminence, (4) proportionality, (5) consideration to the equities involved, and (6) duty to effect reparations whenever possible (Rodick, 1928). Much of these still permeate the ILC's modern conception of the state of necessity and resonate with the doctrinal requisites imposed on self-defense -as an exercise of the fundamental right to self-preservation of the State- under the aegis of article 51 of the UN Charter, even if they're not legislated into the requisites.

It is precisely because of this higher normative threshold that it seems to offer a framework that is simultaneously respectful of the legitimate expectations of the territorial State to have its rights under article 2(4) UNC respected while enabling a non-condemning alternative for the defending State when an attack by a NSA physically situated in the territory of the 'attacked' State occurs. In raising the bar by demanding a stricter scrutiny of the existence of necessity, the defending State need not be hopelessly subject to attacks by NSAs without being able to see to its own essential interests in the face of an uncooperative territorial State. In the same train of thought, it should be noted that the ILC's $5^{\text {th }}$ comment under article 25 references the Caroline incident and qualifies it not as self-defense, but rather as a clear-cut case of the operation of the state of necessity (ILC, 2001) which is exactly the claim put forth by this piece.

\subsection{The conditions for operation of article 25 of the DARSIWA}

The forcible conclusion (or perhaps the cause) of the very existence of the state of necessity as a circumstance that precludes wrongfulness, is that it safeguards "the most important of these fundamental rights of States [which is] that of existence, which involves the rights of self-preservation and defense" (Hershey, 1927 , p. 231). This is perfectly aligned with the ontology of the exception in that it seeks to protect essential interests of the State that may run counter to its obligations and in detriment of the rights of other States. In order to achieve this, necessity requires a balancing of protected rights against those that would suffer from the breach.

This is precisely the quid of the issue, as observed by Boed, "the balancing test in the provisionally adopted text of article $33^{(14)}$ of the ILC's Draft Articles on State Responsibility is designed to weigh inconsistent interests of two States (...)"(15) (Boed, 2000, p. 4), from this it follows, that the ILC drafters meant to codify a flexible regime, simultaneously mindful of the most important interests of States without negating the efficacy of international obligations.

Fenwick describes the difficulties of the balancing test in writing that " $t]$ he conflict of international rights thus resulting is governed by a few general principles of law, which are, however, so vague as to leave it an open question in many cases whether the right of one has justified a breach of the right of the other" (Fenwick, 1965, pp. 142-143). This is exactly applicable, letter by letter, to the current law governing self-defense and even more so to the question of whether self-defense is admissible vis a vis non-State actors in the territory of a third non-consenting State, with one minor caveat: the defense of essential interests of the State, like survival, is not understood in the context of the law of

(14) Now article 25

(15) See also Report of the International Law Commission on the Work of its Twenty-Seventh Session, U.N. Doc. A/10010/Rev.1 (1975), 51-59, U.N. Doc. AICN.4/SER.Al1975/Add.1; Report of the International Law Commission on the Work of its Thirty-Second Session, U.N. Doc. A/35/10 (1980), 26-34, U.N. Doc.AICN.4/SER.A/1980/Add.1. 
responsibility as a right ${ }^{(16)}$, but rather as a way to evade the responsibility that accompanies the breach of obligation (Ago, 1980).

Ago's conclusion that self-preservation is -operationallyan excuse rather than a right is seemingly backed by judicial practice (Cheng, 2006) and by a noteworthy lack of substantial State protest.

Notwithstanding the rough edges in its definition, at least there's widespread agreement on the requirements necessary for the plea of necessity to operate. These are laid out in article 25(1)(a) of the DARSIWA and are composed of (1) the essential nature of the protected interest, (2) the gravity of the harm threatened or inflicted, and (3) the need of immediate action.

From among these three requirements, the first one poses severe challenges in terms of interpretation. The ILC itself declined to provide a definition or a metric of comparison as to what constitutes an 'essential' interest (ILC, 2001). This lack of definition ought to be interpreted as a deference to the subjective classification of the State, and as a function of the difficulty to agree on a fixed set of situations meriting such a classification. The preference for the case-by-case analysis of each scenario lends credence to the idea that the nature of 'essential' of the interest is context-dependent and should be thus assessed. This deference to the State is not, however, without limits. The ILC has opined that "[t]he extent to which a given interest is essential depends on all the circumstances and cannot be prejudged. It extends to particular interests of the State and its people, as well as of the international community as a whole" (ILC, 2001). In other words, while the burden of proving the essential nature of the interest is on the claimant of the necessity, the analysis of whether the interest is fundamental must be carried out in light of the context and circumstances surrounding the situation.

The dangers in this position are manifold. It opens the door for pronouncing virtually anything as an essential interest and therefore negating the extraordinary character of the plea of necessity. Regardless, the very fact that the essential nature of the interest ought to be demonstrated in order for the claim of necessity to hold, provides a much stricter standard than that of the law governing self-defense, where any armed attack satisfying a minimal degree of gravity will warrant lawful retaliation ${ }^{(17)}$. This is already a first positive for necessity as a normative framework to complement the law governing the use of force in the UNC context. Precisely because of its exceptional nature and the need for an interest above mere topical allegations of sovereignty to be demonstrated, it offers -at least- a chance for differentiated and strict scrutiny where self-defense cannot. Additionally, the fact that the argument for the essential character of the interest ought to be put forth after the unlawful act does not, at all, subtract from the usefulness of it. By any metric, if the essential nature of the interest threatened or attack is not proven, then the justification fails and the action is outright illegal, with the necessary consequences ensuing, much as it can happen when a claim of self-defense under article 51 UNC is brought to the UNSC.

As to the second and third requisites codified by the ILC, namely that of the gravity and imminence of the peril, the Commission went on to add that:

Whatever the interest may be, however, it is only when it is threatened by a grave and imminent peril that this condition is satisfied. The peril has to be objectively established and not merely apprehended as possible. In addition to being grave, the peril has to be imminent in the sense of proximate (ILC, 2001, p. 83).

While these conceptual contributions from the ILC surely are useful in ascertaining the limits of operation of the state of necessity, they contribute little to actually defining what gravity and imminence are. The exact legal meaning and import of those two words is the subject of several rivers' worth of ink courtesy of scholarly writing and then some more brought by international jurisprudence(18).

If self-defense claims under article 51 of the UN Charter may be used as a mirror for the operation of the plea of necessity when it concerns response to armed attacks by NSAs (and the contention here is that they can to a certain extent), then to look for orientation on

(16) Which it may very well be, if seen as a function of delegated sovereignty as suggested by modern contractualists (Dobos, 2011) and also as a consequence of the designation of self-defense as an inherent right under article 51 of the UN Charter. That point is, nevertheless, besides the scope of this article since the operation of the regime of State responsibility characterizes this right as an excuse to evade responsibility and not as a "clash of rights".

(17) As occurs with virtually any letter addressed to the Security Council concerning an article 51 notification where mention to the events that triggered the exercise of self-defense are typically never discussed and, at best, barely mentioned in passing.

(18) Specifically on the subject of imminence, the very existence of incredibly robust volumes of results for any search for "preventive self-defense" or "anticipatory self-defense" bear witness to the diverging views concerning the necessary temporal threshold of a threat in order for measures to be available to the threatened State. 
the requisites of gravity and imminence the emphasis should be put on the proxy concepts of necessity and proportionality because of their intimate relationship. The rationale behind the likening of these requisites flows from the notion that the gravity and imminence of the peril provide the metric to assess the necessity and proportionality of the response in a sort-of symbiotic normative relationship. If the peril or threat is minor or trivial, then any armed response to it will necessarily be disproportionate. If the threat cannot be objectively assessed to exist, then the response is unnecessary ${ }^{(19)}$.

As the ICJ observed in the Wall opinion, under the UN Charter any armed attack by another State triggers the right of self-defense (ICJ, 2004). Regardless of this the Court has occasionally analyzed whether the original use of force constituted a grave violation of article 2(4) giving way to the exercise of self-defense and accordingly qualified the necessity and proportionality of the defensive force employed. By doing this, the Court has provided -maybe without actively meaning to- a judicial standard to qualify both the gravity and (to a lesser extent) the imminence of the peril that would then trigger the right of self-defense (or the plea of necessity here). Note that in the Oil Platforms case the ICJ was unpersuaded by the US' arguments concerning the obiter on the use of force and ended up finding that the US' actions were neither necessary nor proportional under the circumstances as appraised by the Court, which surprisingly enough, engaged in a scrutiny seemingly more akin to the plea of necessity under the DARSIWA than that of self-defense, As hinted by Taft, the Court seemed to suggest that unless a minimal threshold of gravity is evident in the use of force, then self-defense will not become an option because it would be unnecessary and disproportionate (Taft, 2004). Similar conclusions were reached by the Court in the Armed Activities on the Territory of the Congo case, it found that the preconditions for the exercise of self-defense were not satisfied and, in consequence, it was not tasked with analyzing whether Uganda's actions were necessary or proportionate (Damrosch, Henkin, Murphy, \& Smit, 2009).

On the specific issue of imminence, the ICJ understood in Gabckicovo that the temporal scope need not be materially and temporally immediate but rather proximate or objectively foreseeable (ICJ, 1997). As the ILC noted, the clear establishment of the objective existence of the peril based on reasonably available evidence at the time of the infringing measure is enough to open the way for the claim of necessity (ILC, 2001).

As is evident, the analytical framework of the factual test needed to ascertain the validity of the claim of necessity is actually fairly stringent, albeit highly contextdependent. The best proof of the exceptional nature of this justification is to be found precisely in its application by the international judiciary and arbitral tribunals. As noted by the Commission in its $14^{\text {th }}$ commentary to article 25 there is ample evidence of the claim of necessity being submitted to international tribunals in order to elude responsibility (ILC, 2001) and, consequently, a display by those many judicial and arbitral instances of a very rigorous scrutiny of the factual underpinnings that uphold the validity of the claim (Paliouras, 2016).

The ICJ -again in the GabcikovoNagymaros Project case- provided useful theoretical insights in order to check whether the plea of necessity (as codified by the ILC) could apply to any given situation. It wrote:

In the present case, the following basic conditions (...) are relevant: it must have been occasioned by an "essential interest" of the State which is the author of the act conflicting with one of its international obligations; that interest must have been threatened by a "grave and imminent peril"; the act being challenged must have been the "only means" of safeguarding that interest; that act must not have "seriously impair[ed] an essential interest" of the State towards which the obligation existed; and the State which is the author of that act must not have "contributed to the occurrence of the state of necessity". Those conditions reflect customary international law (ICJ, 1997, paras. 51-52).

If with the enunciation put forth by the ILC, the Court seems to develop pretty much the same standards in a more articulated and demanding way. The requisites for the claim of necessity to hold, according to the Gabcikovo bench are (1) the threat or harm to an essential interest of the State, (2) the existence of grave and imminent peril, (3) the lack of less harmful alternatives, (4) the lack of prejudice or harm to the essential interests of the State to which the original obligation was owed, and (5) the lack of contribution to the peril by the claimant of necessity. These,

(19) It would be intellectually dishonest, however, to simply lump both sets of requisites together without disclaiming that the threshold for the application of UNC article 51 is the occurrence of an armed attack by another State, which is exactly the very requisite that this piece seeks to elude to avert the defenselessness of the attacked State when the author of the attack is a NSA. 
do not diverge greatly from the ones included in article 25 of the DARSIWA except for the lack of a less damaging option. In this context, the difference does not warrant too much explanation because if there were a less harmful option, then the claim of necessity (be it under the DARSIWA or under the standard set by the ICJ) would be precluded from operation because the infringement was not really necessary. As noted by the ILC, the course of action taken must be the only way available to safeguard the imperiled interest. The plea of necessity would then be excluded if there are other legal means available, even if they may be more costly or less convenient as long as they are lawful (ILC, 2001).

\subsection{The compatibility of article 25 of the DARSIWA with the UN Charter's article 51}

Article 55 of the DARSIWA is clear in indicating that the articles exist without prejudice to special regimes and become inapplicable in the face of lex specialis. The ICJ has upheld this maxim in both the Tehran Hostages case in regards to diplomatic law and in the Gabcikovo-Nagymaros Project case vis à vis treaty law. Article 25 of the DARSIWA itself curtly states that "necessity cannot be invoked if the primary rules exclude the possibility of invoking necessity". The latter, of course, is not the case here. Even if article 51 UNC restricts self-defense to armed exchanges between States, there is no explicit exclusion of the invocation of the state of necessity. In fact, necessity is contained within the very terms of reference that States claim before the Council in exercising their right of self-defense.

Rules of conflict like article 55 DARSIWA only become applicable when there is a conflict of norms. Namely, when the content and purpose of rules is contradictory or would lead to opposing results. That is far from the case with the state of necessity and the Charter norms on self-defense. Since one looks at the responsibility of State in safeguarding essential interests, and the other caters to the admissibility of actions which would prima facie constitute a breach of interstate peace and security (and thus, legality), there is no conflict evident between the purposes and texts of the norms.

In support of this, the so-called 'Vienna rules' (Bjorge, 2018) contained in articles 31-33 of the Vienna Convention on the Law of Treaties allow for the harmonized interpretation of "any relevant rules of international law applicable in the relations between the parties" in article 31(3)(c). Hence, the application of article 51 UNC need not exclude (nor should it) the invocation of necessity under the terms of the DARSIWA since they're not incompatible and the former does not explicitly exclude the latter.

Even more so, the welcoming of the state of necessity into the fold of Charter-governed self-defense via the UNSC would cater to an actual need of the international community by bridging the gap created by the exclusive interstate nature of article 51 UNC and allowing for self-defense against NSAs under the watchful eye of the Council, which can then ensure both the conformity with international peace and security and, by way of consequence, with the jus ad bellum.

In this same train of thought and to quote Schachter referring to the potential expansion of article 51 of the UNC, it is true that States exhibit significant reluctance to "approve uses of force under expanded conceptions of selfdefense (...). Such reluctance is evidence of a widespread perception that widening the scope of self-defense will erode the basic rule against the unilateral recourse to force" (Schachter, 1991, p. 171). However, and as pointed out several times in this piece, the alternative to expanded interpretations or lateral solutions (like the state of necessity) does not in and of itself threaten to erode the prohibition against the use of force, but rather to update it to modern needs arising out of the ever-changing nature of conflict.

To avoid the risks highlighted by Schachter, the responsibility of scrutinizing the validity of the claim of the state of necessity as a stand-in for self-defense in the case where authorship of the attack rests on a NSA in the territory of a nonconsenting third State should be entrusted to institutions capable of answering in real time (or as close as possible to) and which have the authority to produce qualifications on the legality and legitimacy of a given use of the plea of necessity. The first of these requirements is a direct function of the immediacy built into the attack itself and the need for defense without delay, which is hardly accommodating with the parsimonious times the international judiciary takes in adjudicating claims. The second requirement proposed goes to the need for a body capable of simultaneously analyzing both the legal and political dimensions of the actions taken when the attack and the response present themselves. It is for this reasons that this paper suggest that no better alternative may be found throughout international law than the United Nations Security Council. 


\section{Operationalizing the state of necessity as an analogue of article 51 of the UN Charter}

Arguably, the main aim of the UN Charter was to establish "an institutional framework regulating the use of force by substituting unilateral uses of force with collective ones when certain situations of necessity, as defined by the system, arise" (Tsagourias, 2011). But, as noted earlier, the right of self-defense was left explicit in the text of the agreement in recognition of the fundamental importance attached to the ability of the State to preserve itself (Waltz, 1959). However, and as shown above, this conventional iteration of the right of self-defense was built on the notion that the only legally relevant uses of forces would be those conducted between States.

This is perhaps the reason why Tsagourias argues that "[w] hen a state for examples uses force in self-defense, it asserts a right; it does not need to invoke necessity in order to justify its right of self-defense as such" (2011, p. 29) without pondering that the right of self-defense as enshrined in art. 51 UNC only covers interstate uses of force and condemns to illegality those not encompassed under the three exceptions to the prohibition of article 2(4). Since self-defense against NSAs in the territory of a third non-consenting State is not included in the exceptions to the prohibition on the use of force, then it becomes necessary to find a legal path to safeguard the essential interest of the attacked State.

The state of necessity could constitute the legal foothold necessary to allow for such exercises of self-defense if the requisites laid out in article 25 of the DARSIWA are met (which would not be terribly difficult, as incidents like the Caroline or Gorostiza have shown).

However, the typical processes associated with adjudication of responsibility such as bilateral claims commissions or recourse to judicial or arbitral settlement would belie the imminence of the situation that triggers the illegality, and thus condemn the claim to epiphenomenality. In this context, the first argument for proposing the UNSC as an ideal venue for airing such claims is one of efficiency: The reporting duties stemming from article 51 UNC and State practice provide the perfect vehicle for alerting the Council when force is used against an NSA in the territory of a third State that has not consented such an action (regardless of its position vis à vis the NSA). The best proof of this is that States are already doing it even if the legality of the use of force is still up for debate, as the recent Arria Formula Meeting of February showed.

There are many counters to the argument of using the UNSC as an ideal venue for the examination of whether necessity justifies the attack against the territorial integrity and sovereignty of the territorial State from which the NSA operates. Kelsen points out the root of the most prevalent ones by noting that the UNSC's role "is not to maintain or restore the law, but to maintain or restore peace, which is not necessarily identical with the law" (Kelsen, 1950, p. 294). Tsagourias follows him in pointing out that the measures adopted by the UNSC "can be coercive or non-coercive, but they are not equivalent to legal consequences as in the law of state responsibility" (Tsagourias, 2011, p. 30). Thus, the most pervasive arguments against the idea of this paper lie within the realm of the 'political character' of the decisions of the UNSC. These will be addressed by offering one simple rebuttal: politics -such as those of the UNSC- don't exist in a vacuum, much less so in international law where all ability is derived from State concession. Even while being preeminently political in its' daily operation, the Council is bound by international law and its par excellence a venue where the currency is law (even if it serves as a dressage for politics) (Johnstone, 2003). The Council constantly makes legal, and it seems a disservice to artificially separate 'peace and security' from 'rule of law'.

In those few instances where the Council has in fact reprimanded uses of force for being aggressive, such as the Israeli bombing of the Osirak reactor, its answers are deeply embedded in legal terms and cause legal consequences. In the majority of cases where it has been silent, its inaction cannot and should not be equated with tolerance or legality (that is precisely where its political nature shows itself). It is this very fluidity that has enabled the Council to procure a measure of success in its task, but it by no means signifies that it is precluded from carrying out legal analyses and assigning consequences to illegal conducts. In short, politics and law can and do mix, even if they mostly don't at the seat of the Council, which by no means entail that they can't. As an example of this, note how the Council has the power to qualify a use of force as aggressive under the terms of the UN Charter and aided -among others- by the definition of aggression. Is that not, perchance, a most pure form of legal determination of responsibility as a consequence of a juridical qualification of any given action? 


\subsection{The role of the UNSC in qualifying the validity of the exception}

If then, the claim of state of necessity is legally feasible in order to exempt a State from responsibility when it conducts attacks against a NSA in the territory of a non-consenting third State, the next pressing question is about the logistics of such a claim: would the UNSC be legally competent to determine the existence and validity of the alleged state of necessity plea?

The most tempting and straight-forward answer would be that the State who has suffered the injury to its sovereignty and territorial integrity (assuming it is an unwilling host of the NSA and that it refuses to invite the originally attacked State to intervene on its behalf) should have recourse to judicial settlement as stated in article 33 of the UNC. However, if viewed from the perspective of the State suffering the attack carried out by the NSA, this makes little sense both in temporal and logistical terms. Firstly, it would lack jus standi to make any claims (not being the aggravated party on account of being unable to show harm caused by another State); secondly, the institution of proceedings before international tribunals is anything but expedite (which would then render pointless the situation of urgency and imminence of the attack), and lastly, it completely ignores the likely reticence of the defending State to have its actions submitted to judicial scrutiny (Gomez \& Montiel, 2021). Without prejudice to the submission of the case to the international judiciary once the dust has settled, there is another instance that offers a much faster and equally legal setting to analyze the potential claim of necessity in using force against the territorial integrity of the third State: The United Nations Security Council.

In its Nicaragua ruling, the ICJ affirmed without controversy that any measures taken under article 51 must be immediately reported to the Council (ICJ, 1986) and that it is tasked with determining the conformity of the instance of self-defense with the law governing the use of force between States. The same is stated by article 51 ejusdem in its second sentence. However, as noted at the outset of this work, the exercise of self-defense against NSAs (as differentiated from interstate use of force) seems to be outside of the scope of activity of article 51 (hence the need to have recourse to the law governing State responsibility). The reason for this is that NSAs are not States and therefore any armed attack would fail, by reason of its authorship, to meet the threshold required by article 51 (Gill \& Tibori-Szabó, 2019) which would therefore theoretically negate any obligation of reporting to the Council on the part of the defending State.

However, this interpretive syllogism is not entirely faithful to the truth of State practice. As Lewis, Modirzadeh, and Blum have identified, there is ample practice in the context of the UNSC of informing the Council when measures are carried out under self-defense against non-state actors to the tune of some 118 instances since the year of 1951 and until 2018 which have involved instances of self-defense against NSAs or States and NSAs jointly (Lewis, Modirzadeh, \& Blum, 2019). This has become especially recurrent in the context of the invasions of Iraq and Afghanistan in the early 2000's and later on with the measures taken to combat the so-called Islamic State of Syria and the Levant (ISIL/Daesh), it is also a constant for Israel as a function of its refusal to recognize Palestine as a State and thereby treating its government as an NSA.

It could then be argued at face value, and pending a conscientious review of concurrence of State practice and opinio juris, that a customary obligation may exist or is -at the very least- in formative period, which extends the duty of reporting measures taken under article 51 even if the target is not directly another State (with the ensuing vicious circle question of whether it really is an article 51 report or something else). As pointed out by the ILC, the practice of International Organizations and of member States within them can -in principle- constitute acceptable practice in determining the existence of rules of customary law (ILC, 2018). This is further supported by the near-monopoly the UNSC holds over international peace and security and its 'primary' responsibility in the maintenance of it. As a consequence, even if it is not mandatory, the practice of reporting instances of self-defense to the Council should be analyzed from the lens of material reality and the primacy of State practice, as observed by the ICJ in the Continental Shelf case concerning Libya and Malta (ICJ, 1985). From this it follows that States can notify the Council (even if they're not explicitly obligated to) of any measures taken under the aegis of self-defense against NSAs in the territory of a third non-consenting State.

If they can do so in respect of article 51 measures, would itnot be the same hold largely true if the allegation were not one of self-defense but of a permissible violation of article 2(4) UNC excused by the state of necessity in the supra referenced terms? The argument here is that they are in fact allowed to do so as a function of identity in nature 
and purpose of the claim in a teleological reading. As noted earlier, article 51 is an exception (inherent and inalienable as it may be, but exceptional nevertheless) to the prohibition on the use of force against the territorial integrity and political independence of the aggravated State, therefore, the legal usefulness of claiming self-defense is to exclude the possibility of labelling the measures as incurring in the use of aggressive force. The same rationale applies for claiming the existence of a state of necessity to justify the adoption of measures that would otherwise violate article 2(4) UNC.

The effect of the validity of such a claim is precisely the erosion of unlawfulness of the action, in the intelligence that the preservation of essential interests of the State is at play here and thus warrants the commission of a prima facie unlawful act. The conclusion is that it would be arbitrary and senseless to distinguish between a claim of force being used in self-defense under article $51 \mathrm{UNC}$ and one of state of necessity made under article 25 of the ILC's DARSIWA since these two are motivated by almost identical circumstances (armed attack by another State and armed attack by a NSA), seek to safeguard the same essential interests (even if the threshold required by article 51 UNC is lower in that any armed attack by another State warrants self-defense and the claim of state of necessity would require demonstration of the specific essential interest in jeopardy), and have the same effect (exempting the classification of the measures taken as violations of article 2(4) UNC).

Thus far, it is evident that States can report to the UNSC the measures adopted against the armed attack carried out by an NSA justified under a state of necessity, because they do. It has also been shown that the Council is competent to receive such a notification since the activity falls squarely under the category of 'international peace and security', but then the most important question arises: does the UNSC possess the power to qualify the validity and legality of such actions?

Even with respect of de jure article 51 communications, the Council rarely responds officially to self-defense notifications. Bearing in mind that if the UNSC reaches the conclusion that a particular instance of self-defense fails to conform to the parameters emanating from article 51 , the forcible conclusion would be that such an action constitutes a breach of article 2(4) UNC. However, nowhere in the law are declarations of responsibility automatic or self-executing, and the law governing the use of force is no exception. In this context, the UNSC would have to formally declare the existence of a breach of international peace and security as indicated by article 39 UNC and then proceed to declare responsibilities and/or award reparations. Nevertheless, this is seldom the case with the UNSC. In most instances, the Council opts for silence, in some other select ones it has chosen non-condemnatory language ordering the re-establishment of the previous status quo, and only exceptionally has it outright qualified an action carried out under the shadow of article 51 UNC as illegal. As noted by Sievers and Dawn this variable practice pursuant to article 51 is compounded by the fact that the UNSC typically avoids determinations as to the self-defense nature of an action reported to it (Sievers \& Daws, 2014). However, the fact that it doesn't qualify does not entail (by and large) that it can't.

The practice of the UNSC in dealing with communications concerning self-defense has been mostly of silence (Lewis, Modirzadeh, \& Blum, 2019), with the notable exception of S/RES/487 (1981) dealing with the Israeli preventive strike against the Osirak reactor in Iraq and a handful of others. Thus, it is safe to conclude that the Council rarely qualifies the legality of allegations of self-defense (Kerr, 2012). This silence can be read in several ways. On the one hand, given its mandate to monitor and uphold international peace and security, the silence of the Council when presented with an article 51 communication can be read as a conclusion of lawfulness (Quigley, 2003) much in the same logic that silence creates acquiescence under certain circumstances. It has also been posited that silence can amount to mere toleration without necessarily conveying acceptance or lawfulness (Orakhelashvili, 2015), or alternatively one could argue that no legally relevant effect should be deduced from the inaction of the Council (Montiel, 2021) as "a handful of States cannot speak for all States, and it is improper to infer agreement from silence" (Glennon, 2001, p. 75). Regardless of this, article 51 UNC calls for an ex post control of the conformity of the measures adopted by the defending State and it is patent that the Council can and should answer as a matter of law. This is the exact same holding of the ICJ in its Nicaragua ruling, later upheld in the Oil Platforms Case (ICJ, 2003), in which the Court found the UNSC to be competent to determine lawfulness of the whose justification is sought on the basis of self-defense. In this intelligence, the answer is almost obvious, even if the Council is not a judicial organ, it is required by the Charter to analyze the conformity of any action taken under article 51 UNC with the law governing self-defense and use of force in general.

More to the point, if the Council is tasked 
with receiving article 51 UNC communications and qualifying the legality of the use of force therein exerted, possesses the competence to declare the existence of a breach of international peace and security, and has the primary responsibility for the maintenance of international peace and security as per article 24 of the UNC, alongside with the power to adopt any decisions it deems necessary for the restoration of international peace and security (such as declaring the illegality of any given use of force), then the doctrine of implied powers as put forth by the ICJ in its Advisory Opinion concerning Reparations for Damages Suffered in the Service of the United Nations (ICJ, 1949) would force the conclusion that the Council needs to have such a power in order to carry out its responsibilities effectively ${ }^{(20)}$.

Nevertheless, authors such as Klabbers have argued against such a notion claiming that the UNSC is inherently political in nature and should not be deemed to have the power to determine juridical situations (Klabbers, 2015). This conclusion seems to run counter to the bona fide interpretation of the UN Charter and the relevant dicta of the ICJ concerning the law governing the use of force. The fact that it is a political body in nature need not necessarily compromise the legitimacy of juridical determinations the Council may reach in qualifying the legality of self-defense, it may even enrich it by virtue of 'the power of the better argument' (Johnstone, 2003) and because the of political counter-weights present in the Council under the guise of technical arguments based in the law.

This goes to show that the Council can in fact determine the legality of measures taken under article 51 UNC. If the same test of identity applied a few paragraphs ago is applied here, there is no reason why the Council would be precluded from entertaining a debate on the legality of measures adopted against an armed attack of a NSA justified in a state of necessity. It would, after all, be an act susceptible of constituting breach of article 2(4) of the UNC and would therefore merit the Council's attention with a view to determining whether or not such use of force is aggressive. This in turn, falls under the purview of the Council without the need of any further analysis.

Solid evidence for this possibility, is provided by article 2 of A/RES/3314 (XXIX) which states that "the Security Council may, in conformity with the Charter, conclude that a determination that an act of aggression has been committed would not be justified in the light of other relevant circumstances". While the cited text is in the negative, it does reveal that the Council may look to external circumstances (such as the existence of a state of necessity) in determining whether a given use of force constitutes an act of aggression under article 2(4) of the UNC. In fact, it is this same article 2 of the definition of aggression resolution of the General Assembly that utilizes the language of justification to preclude illegality (bearing in mind that aggression is clearly illegal under Charter law and a breach of a myriad of international obligations), and thus signals to the compatibility of the regime of excuses in analyzing uses of force as per the DARSIWA.

Nor does it warrant further scrutiny the question of whether the Council may analyze the validity of the claimed state of necessity on the part of a State countering an attack by an NSA. The UNSC has no fixed parameters (other than necessity and proportionality) to determine whether the use of force in selfdefense is legal or not, but can -and always does- look to the UN Charter, and general international law for guidance. In this context, it is especially noteworthy that necessity is already built into the criteria for assessing the legality of measures adopted in selfdefense, as was held by the World Court in the Oil Platforms case (ICJ, 1986), what the here proposed solution would entail is merely providing a more structured scrutiny of the necessity requirement in order to preclude the wrongfulness of the use of force against the territory from where the NSA operates.

The notion entertained here is, of course, one concerned with possibility and competence of the Council. A different one -and perhaps more pressing- is whether the Council (and the member States of the UN) will entertain such claims. The answer to such a question would necessitate member States bringing the claim forth and seeing if, in being demanded a determination, it will oblige. There is nothing to suggest that the practice of the UNSC wouldn't evolve to meet such requirements if pressed to by the membership of the Organization in the search for a viable alternative to being fated to suffer damage as a consequence the unwillingness or inability to foresee this modality of violence back when the UNC was being drafted.

(20) Also note how the Council occasionally dabbles in quasi-judicial exercises with the Al-Qaeda Sanctions Committee and in wouldbe normative practices when it issues thematic resolutions like s/res/1882 (2009), none of which have been met with protest from Member States, which would then offer the reasonable assumption that such a behavior from the Council is -at least- not ultra vires. 


\section{Conclusions}

As reality has shown, the particular mode of political violence that occurs when NSAs use the territory of a third State (with or without its toleration) to launch armed attacks against another State is not a new phenomenon and is, presumably, here to stay. An international law which fates the attacked State to such suffering is not one particularly coherent with the principle of sovereign equality and also one that fails to recognize that the State, and its sacred duty to protect its territory and people, are at the center of the normative order. Therefore, it stands to reason that the law would -by omission or lack of foresight- bind States to suffer such attacks without remedy.

This article has shown that, unless clear indicated otherwise, the law governing the responsibility of the State for internationally wrongful acts is applicable to the rules governing self-defense (in the context of the use of force regime) when the author of the attack is not a State but an NSA. Additionally, the identity in object and purpose (and requisites of operation) of both regimes would render arbitrary any attempt to bar the application of the state of necessity to the situation where an NSA attacks a State from the territory of a third State that fails to honor its duty to prevent damage from its territory to the defending State.

The realization that -although theoretically constrained by the interstate dynamics of the UN Charter- the UNSC has nearabsolute monopoly on the scrutiny of the use of force by States should caution that attempting to divert such a competence is an exercise in wishful thinking. The powers and attributions of the Council have grown over the years because the realities of politics and law have demanded it (and because States rarely protest the decisions of the Council because it acts on delegated authority from all the members of the UN). After all, the Council is little more than the voice of its members (Hurd, 2018) and its politicized application of the law is -to the chagrin of many observers- an inescapable feature of the use of force system. In this context, the argument against allowing the Council to examine the claim of necessity when defending against the attack of an NSA from the territory of a third non-consenting State on the grounds of its political nature would certainly raise questions as to why such an examination is not questioned when the participants of the exchange of violence are only States.

As annotated above, Schachter (1991) cautioned against licentious interpretations of self-defense that could have the effect of eroding the prohibition on the use of force, in the way that doctrines like the 'unwilling or unable' do. Arguably, this concern reflects the need for strict rules that are not easy to bypass via semantic sleight of hand on the part of war-prone States. The proposition of this paper seeks to uphold the spirit of Schachter's advice. In importing the rules governing the plea of necessity and incorporating them into the analytical toolkit of the UNSC, far from attempting to erode the prohibition against the use of force, the aim is to strengthen it and to update it so that it may better serve its real purpose: guaranteeing international peace and security in a way that is respectful of the sovereignty of all States involved without imposing undue burdens upon them. The idea is to use already existing law to fill the lacunae that may be filled, as is the case here.

In a system, such as international law, which has its origin in the freedom of States there is a severe difference between self-limitation in the interest of peaceful coexistence and a shackle impeding the defense of the population and territory of the States themselves on account of a normative oversight of seven decades ago. The claim of the plea of necessity arbitered by the UNSC is a legally coherent attempt to turn the latter into the former in a way that is respectful of existing law and cautiously deferential to national sovereignties.

\section{Bibliographic references}

Ago, R. (1980). Addendum to the Eight Report on State Responsibility, UN Doc. A/CN.4/318/ADD.57. Yearbook of the International Law Commission.

Akande, D. \& Liefländer, T. (2013). Clarifying Necessity, Imminence, and Proportionality in the Law of Self-Defense. American Journal of Intenrational Law, 107, 563-570.

Arimatsu, L. \& Schmitt, M. (2021). The Plea of Necessity: an oft overlooked response option to hostile cyber obperations. International Law Studies, 1172-1198.

Bethlehem, D. (2012). Self-Defense Against an Imminent or Actual Armed Attack by Nonstate Actors. American Journal of International Law, 106, 769-773.

Bethlehem, D. (2021). Self-Defense against an imminent or actual armed attack by nonstate actors. American Journal of International Law, 106, 770-771.

Bjorge, E. (2018). The Vienna Rules, Evolutionary Interpretation, and the Intentions of Parties. In A. Bianchi, D. Peat \& M. Windsor, Interpretation in International Law (pp. 189-203). Oxford University Press.

Boed, R. (2000). State of Necessity as a Justification for Internationally Wrongful Conduct. Yale Human Rights and Development Law Journal, 3(1), 1-44. 
Britannica, E. (2021, August 14). Dumbarton Oaks Conference. Encyclopaedia Britannica. https://www.britannica.com/event/ Dumbarton-Oaks-Conference

Chachko, E. \& Deeks, A. (2016, October 10). Which States Support the 'Unwilling and Unable' Test?. Lawfare Blog. https://www.lawfareblog. com/which-states-support-unwilling-and-unable-test\#UnitedStates

Cheng, B. (2006). General Principles of Law as Applied by International Courts and Tribunals. University College London.

Crawford, J. (2019). Brownlie's Principles of International Law (9th edition). Oxford University Press.

Damrosch, L., Henkin, L., Murphy, S. \& Smit, H. (2009). International Law. Cases and Materials (5th edition). St. Paul: West.

DeLaurentis, J. (2021, March 16). Letter dated 8 March 2021 from the Permanent Representative of Mexico to the United Nations addressed to the Secretary-General and the President of the Security Council. United Nations Digital Archive. https://documentsdds-ny.un.org/doc/UNDOC/GEN/N21/066/46/PDF/N2106646. pdf?OpenElement

De la Fuente, J. (2021, February 24). Letter dated 8 March 2021 from the Permanent Representative of Mexico to the United Nations addressed to the Secretary-General and the President of the Security Council. United Nations Digital Archive. https://documentsdds-ny.un.org/doc/UNDOC/GEN/N21/066/46/PDF/N2106646. pdf?OpenElement

Dobos, N. (2011). Insurrection and Intervention: The two faces of sovereignty. University Press.

Drnas de Clément, Z. (2002). Las normas imperativas de Derecho Internacional general (jus cogens). Dimensión sustancial. In Z. Drnas de Clément, \& M. Lerner, Estudios de derecho internacional en homenaje al profesor Ernesto J. Rey Caro (pp. 647-680). Marcos Lerner Editora.

Fenwick, C. (1965). International Law (4th ed.). Appleton-CenturyCrofts.

Franck, T. (1970). Who Killed Article 2(4)? or: Changing Norms Governing the Use of Force by States. American Journal of International Law, 809-837.

Gill, T. \& Tibori-Szabó, K. (2019). Twelve Key Questions on Selfdefense Against Non-State Actors. International Law Studies, 468-503.

Glennon, M. (2001). Limits of Law, Prerogatives of Power: Interventionism After Kosovo. Palgrave MacMillan.

Gomez, S. \& Montiel, M. (2021, February 19). A Commentary on the Arbitral Award of 3 October, 1899 (Guyana v. Venezuela) jurisdiction ruling: The road to hell is paved with good intentions. Opinio Juris. http:// opiniojuris.org/2021/02/19/a-commentary-on-the-arbitral-award-of-3october-1899-guyana-v-venezuela-jurisdiction-ruling-the-road-to-hellis-paved-with-good-intentions/

Gurmendi, A. (2020, February 17). The Other Carolines. Opinio Juris. http://opiniojuris.org/2020/02/17/the-other-carolines/

Haque, A. (2021, March 24). Self-Defense Against Non-State Actors: All Over the Map. Just Security. https://www.justsecurity.org/75487/ self-defense-against-non-state-actors-all-over-the-map/
Heller, K. (2019, March 19). The Earliest Invocation of "Unwilling or Unable". Opinio Juris. http:// opiniojuris.org/2019/03/19/the-earliest-invocationof-unwilling-or-unable/

Hershey, A. (1927). The Essentials of International Public Law and Organization (revised edition). The Macmillan Company.

ILC. (2001). Draft Articles on Responsibility of States for Internationally Wrongful Acts with Commentaries. Yearbook of the International Law Commission (pp. 1-143). United Nations.

ILC. (2018). Draft Conclusions on Identification of Customary International Law, with commentaries. Yearbook of the International Law Commission.

International Court of Justice. (1949, April 11). Advisory Opinion concerning Reparation for Injuries Suffered in the Service of the United Nations. ICJ Reports.

International Court of Justice. (1949, April 9). Corfu Channel Case (United Kingdom v. Albania). ICJ Reports.

International Court of Justice. (1986, June 27). Case Concerning Military and Paramilitary Activities in and against Nicaragua (Nicaragua v. United States of America. ICJ Reports.

International Court of Justice. (1997, September 25). Gabcikovo-Nagymaros Project Case (Hungary v. Slovakia). ICJ Reports.

International Court of Justice. (2003, November 6). Case Concerning Oil Platforms (Islamic Republic of Iran v. United States of America). ICJ Reports.

International Court of Justice. (2004, July 9). Advisory Opinion concerning Legal Consequences of the Construction of a Wall in the Occupied Palestinian Territories. ICJ Reports.

International Court of Justice. (2005, December 19). Case Concerning Armed Activities on the Territory of the Congo (Democratic Republic of the Congo v. Rwanda). ICJ Reports.

International Law Commission. (2019). Fourth report on peremptory norms of general international law (jus cogens). 71st Session (pp. 1-70). United Nations.

Jellinek, G. (1880). Die Rechtliche Natur der Staaten-vertrage. A. Holder.

Johnstone, I. (2003). Security Council Deliberations: The Power of the Better Argument. European Journal of International Law, 437-480.

Kelsen, H. (1950). The law of the United Nations. Steven \& Sons.

Keohane, R., \& Nye, J. (2000). Globalization: What's New? What's Not? (And so What?). Foreign Policy, 118), 104-119. 
Kerr, O. (2012). A Theory of Law. Green Bag, 1.

Klabbers, J. (2015). Intervention, Armed Intervention, Armed Attack, Threat to Peace, Act of Aggression, and Threat or Use of Force: What's the Difference? In M. Wellers, Oxford Handbook of the Use of Force in International Law. Oxford University Press.

Kotlik, M. (2017). Defying the Theoretical Constraints of State-Centric Approaches: A Review of Non-State Actors in International Law. Israel Law Review, 87-105.

Kretzmer, D. (2013). The Inherent Right to SelfDefence and Proportionality in Jus Ad Bellum. European Journal of International Law, 24(1), 235-282.

Lewis, D., Modirzadeh, N, \& Blum, G. (2019). Quantum of Silence: Inaction and Jus ad Bellum. Harvard Law School Program on International Law and Armed Conflict, 1-79.

Modirzadeh, N. (2021). Statement of Professor Naz Modirzadeh to the UN Security Council on February 24, 2021. Arria-Formula Meeting of the Security Council on the theme "Upholding the collective security system of the Charter of the United Nations: the use of force in international law, non-State actors and legitimate self-defence" (pp. 3-9). United Nations.

Montiel, M. (2021). The Consent-Based Problems Surrounding the Doctrine of the Persistent Objector. Michigan Journal of International Law. Forthcoming.

Montiel, M. (2021, June 23). Fantastical Opinio Juris and How to Find It. Opinio Juris. http://opiniojuris. org/2021/06/23/fantastical-opinio-juris-and-howto-find-it/

O'Connell, M. (2019, March 8). Settling the IndiaPakistan Impasse ... At Last. EJIL: Talk!: https:// www.ejiltalk.org/settling-the-india-pakistanimpasse-at-last/

Orakhelashvili, A. (2015). Changing Jus Cogens Through State Practice? The Case of the Prohibition of the Use of Force and its Exceptions. In M. Weller, The Oxford Handbook of the Use of Force in International Law. Oxford University Press.
Paddeu, F. (2020, August 7). Military Assistance on Request and General Reasons Against Force: Consent as a justification for the use of foce. Legal Studies Research Paper Series(28/2020), 1-47.

Paliouras, V. (2016). State of Necessity and Sovereign Insolvency. In A. Segura, The Reform of International Economic Governance. Routledge.

Permanent Court of International Justice. (1927, September 7). Case of the SS Lotus (France v. Turkey). PCIJ Series A, No. 10.

Quigley, J. (2003). The Afghanistan War and Self-Defense. Valparaiso University Law Review.

Rodick, B. (1928). The Doctrine of Necessity in International Law. Columbia University Press.

Schachter, O. (1991). International Law in Theory and in Practice. Brill.

Sharma, Y. \& Agarwal, P. (2020, May 9). Dealing With Non-State Actors In International Law: The "Unwilling And Unable Doctrine". The Fletcher Forum of World Affairs. http://www.fletcherforum.org/ the-rostrum/2020/5/9/dealing-with-non-state-actors-in-internationallaw-the-unwilling-and-unable-doctrine

Sievers, L. \& Daws, S. (2014). The Procedure of the UN Security Council. Oxford University Press.

Taft, W. (2004). Self-Defense and the Oil Platforms Decision. Yale Journal of International Law, 29, 295-306.

Tibori-Szabó, K. (2011). Anticipatory Action in Self-Defence: Essence and Limits Under International Law. The Hague: TMC Asser Press.

Tladi, D. (2013). An Assessment of Bethlehem's Principles on the Use of Force Against Non-State Actors. American Journal of International Law, 107, 570-575.

Torp, S. (2014). The prohibition of the use of force as jus cogens: Explaining apparent derogations. Netherlands International Law Review, 167-193.

Tsagourias, N. (2011). Necessity and the Use of Force: A Special Regime. Netherland Yearbook of International Law, 11-42.

United Nations. (1945). United Nations Charter. United Nations.

United Nations. (1974). A/RES/3314 (XXIX). United Nations.

Waltz, K. (1959). Man, The State, and War. New Columbia.

Williams, G. (2013). Piercing the Shield of Sovereignty: An Assessment of the Legal Status of the 'Unwilling or Unable' Test. UNSW Law Journal, 36, 619-641.

Ziccardi, G. (2007). Providing a Right of Self-Defense Against LargeScale Attacks by Irregular Forces: The Israeli-Hezbollah Conflict. Harvard International Law Journal, 101-112. 